\title{
MISCELLANEA
}

\section{John Darwall, M.D. (1796-1833) and "Diseases of Artisans"}

\section{A. MEIKLEJOHN \\ From the University of Glasgow}

Since the commencement of the factory system in Great Britain, Birmingham has been a leading centre of manufactures. Throughout this period the industries have been many and various but particularly in the metal trades. In these circumstances it is not surprising that local medical practitioners have shown special interest in diseases of artisans. Indeed in the modern advance of industrial medicine Birmingham has made an outstanding contribution.

Among the early writers in English on trade diseases it is customary to give pride of place to Charles Turner Thackrah of Leeds, whose pamphlet on "The Effects of the Principal Arts, Trades and Professions and of Civic States and Habits of Living on Health and Longevity with a Particular Reference to the Trades and Manufactures of Leeds" was first published in 1831. Ten years earlier, in 1821, Dr. John Darwall, a physician of Birmingham, presented a thesis to the University of Edinburgh, entitled " Diseases of Artisans with Particular Reference to the Inhabitants of Birmingham". As a contribution to the literature of trade diseases the discourse has no great merit, but as an early historical document it seems worthy of record, which, so far as I can discover, it has not hitherto obtained. As was the custom of the time the thesis is written in Latin. I have translated it and in this exercise $I$ have been assisted by reference to the terminology in an article entitled "Diseases of Artisans" which Darwall contributed to the "Cyclopaedia of Practical Medicine" in 1833.

\section{Biographical Note}

John Darwall, the son of the Rev. John Darwall, was born at Deritend in 1796. He was educated at the Free Grammar School in Birmingham under the Rev. John Cooke. In 1813 he became the pupil and apprentice of Mr. George Freer of Birmingham, one of the most distinguished provincial surgeons of his time. He was a very diligent medical pupil and, as revealed by his notebooks, was by no means inattentive to general science and literature. On completion of his apprenticeship, at the age of 20 , he went, in October 1816, to London to attend the hospitals and lectures. During this period he was deeply influenced by the teaching of Mr. Abernethy. In May, 1817, he was admitted a member of the College of Surgeons. The following autumn not content, as is recorded, with the superficial manner in which medicine was, at that time, taught in London, he went to Edinburgh. There he studied physic under Gregory, anatomy under Monro and Barclay, and physiology under
Gordon. At the end of the winter he returned to Birmingham as an assistant to Dr. Freer with whom he continued until 1819. During this period he became interested in the diseases of workpeople and in their places of work. In 1820 he returned to Edinburgh and in that year read a paper on the subject to the Medical Society. The following year he presented his thesis, entitled De Morbis Artificum, for the degree of doctor of

IISSER'TATIO MEDICA

INAUGURALIS,

DE

\section{MORBIS ARTIFICUM,} PRECTPUF.

EORUNI QUI BIRMINGHANIE HABITANT QUas,

ANNUENTE SUMMO NUMNE.

Ex ACCTOKITATE REWreEXDI ADMODCX viR,

D. GEORGII BAIRD, SS. T. P.

ACADEMIE EDINBURCENA PR.EFECTI.

\author{
NeCNoY
}

AMPLISSIMI SENATCS ACADEMICI CONSENSL, ET NOBILISSINE FACLLTATIS MEDICA DECRETO,

Pro Oradu Zactorí,

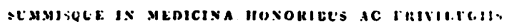

MIE GT ALGITINE CONSHOCENDS,

ERE'DITURLIM EXAMIST SUBJIC:T

JOANNES DARWALL,

Indus:

COLL. MEG. CUIR. LOND. SOC.

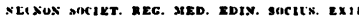

Ttilc est xcirc unumquemque, quid et quando *

atreat.-Cetses Pracfaf. ad Libr. 2.

Kulendis Augusti, horá locoque solitis.

EDINBURGI :

EXCEDEBAT JOANELS NOII.

Incccxxi.

medicine, which he obtained in August, 1821. Immediately after the graduation he returned to Birmingham where he obtained an appointment as one of the physicians to the Birmingham Dispensary. This work was mainly concerned with the care of poor-law patients. His interest was in medicine rather than in surgery and in addition he was attracted to medical journalism. Each quarter he contributed a " Report of Diseases of Birmingham" to the Edinburgh Medical and Surgical Journal. Later he assisted Dr. W. Copland, the editor of the London Medical Repository. He contributed papers on dropsy and spinal and cerebral irritation and on many

* It is expedient for all men to know what precautions to take and when. 
other subjects. In particular he was known for his forthright critical and analytical reviews. For a time he was joint editor with Dr. Charles Hastings of Worcester of the Midland Medical and Surgical Reporter.

He published, in 1830, a small volume entitled " Plain Instructions for the Management of Infants together with an essay on Spinal and Cerebral Irritation ". The following year he achieved his great ambition when he was appointed physician to the Birmingham Hospital.

In 1833 he contributed a well-considered article on "Diseases of Artisans" to the first volume of the " Cyclopaedia of Practical Medicine".

At the early age of 37 years he died under rather tragic circumstances. According to his hospital notebook, on July 30,1833 , he performed a post-mortem examina- tion on a case headed : "Medullary Sarcoma of the Bronchial Glands". The left lung was infiltrated with pus and it would appear that in the course of the dissection he infected a small wound in his left hand. The same night he fell ill with acute fever. Despite the unremitting efforts of his colleagues he died and was buried on August 16, in the family vault at Christ Church, Birmingham.

I am deeply indebted to the University of Edinburgh for permission to publish the thesis and the translation together with the photograph of the original frontispiece ; also to John A. H. Way, M.A., the Humanity Department in the University of Glasgow, who edited the translation and elucidated many passages.

\section{"Diseases of Artisans with Particular Reference to the Inhabitants of Birmingham"}

\author{
By JOHN DARWALL
}

When the world was still new and the inhabitants few, there was scarcely any form of labour apart from agriculture. It is probable also that diseases, like crafts, were equally few. But later when the population was divided into various trades, although some of these may have led to luxury and a comfortable life, diseases likewise increased to the greatest degree. For either the method of work or the materials used in the workharmful in themselves-frequently caused illness among the tradesmen. But it seems surprising that amongst the researches of learning and humanity, very few have inquired into the hardships of tradesmen and even fewer have attempted to relieve the hardships which have been discovered.

As the subject of my discourse the Royal Medical Society prescribed "The Diseases of Artisans". During the summer of 1820 , while resident in Birmingham, I frequently inspected the factories and homes of these workmen and questioned them personally on the subject of their health. On these occasions I personally collected certain facts about the diseases of artisans which appeared to me not altogether unworthy of record. For other information I am indebted to Dr. Booth, formerly president of the Medical Society, who often accompanied me and assisted me by his advice.

Although the trades are so numerous that it is not possible for me to enumerate them all, the causes of ill-health arising from them are fewər. It is seen that immoderate toil, muscular effort, posture, excessive light and noise, variations of temperature, irritation by stone dust or other particles, and chemical irritation are the outstanding causes.

\section{Dissertatio Medica Inauguralis de Morbis Artificum, Praecipue eorum qui Birminghamiae Habitant}

\section{AUCTORE JOANNES DARWALL}

Cum mundus adhuc novus et homines in terris rari fuerunt, illis vix aliud opus erat, quàm agricultura. Probabile est etiam morbos aeque ac artes paucos fuisse. Sed post-quàm variae artes viros diviserunt, quamvis illae ad luxuriam vel commoda vitae conduxisse potuerint, morbi similiter plurimùm auxerunt. Modus enim vel operandi vel materies operis per se noxia, valetudinem adversam persaepz artificibus intulerunt. Mirabile autem inter investigationes scientiae benevolorumque animorum videtur, perpaucos mala artificum quaesivisse, perpausissimos cognita levare conatos esse.

Mihi pro argumento sermonis, regia medica societas morbos artificum tribuit, et per aestatem anni MDCCCXX Birminghamiae habitans, officinas domusque illorum saepissimè visi, et de valetudine suâ ipsos interrogavi. Eo tempore quaedam de morbis artificum ipse collegi, quae non omnino narratione indigna mihi videbantur. Alia quoque Dostori Booth olim medicae societatis praesidi debeo, qui mihi saepe comitatus esi et consilio adjuvit.

Quamvis artes tam multae sunt, ut vix enumerari possint, causae tamen valetudinis adversae ex illis orientis sunt rariores. Praecipue harum videntur esse labor immodicus, conatus muscularis, positio corporis, lux sonitusve nimius, temperiei mutationes, irritatio pulveris lapidum vel aliarum particularum, et irritatio chemica. 


\section{Immoderate Labour}

The evils which derive from immoderate toil chiefly affect children. These young persons either from the poverty of their parents or, what is much more to be condemned, from the greed of employers, are compelled to work at a much lower age than is right. Scarcely three years have passed since the government of Great Britain discussed this problem, and sought the opinions of leading medical men. Of these Mr. Astley Cooper, surgeon, alone gave evidence from his personal experience. Certainly his reputation and acknowledged learning do not permit us to doubt the truth of his judgment. "The effect," said this distinguished gentleman, " which I have observed in many cases, is not only to diminish the stature but also to produce deformity of the limbs ". Robert Owen of New Lanark was questioned on the same occasion and his testimony was to the same effect.

My personal experience, if I may speak of it, fully confirms the judgment of the distinguished Mr. Cooper.

There is an institution in Birminghàm in which 400 children are accommodated. Their ages vary from 1 to 14 years, but they are not compelled to go to work before the age of 7 . At this age they are employed eight hours daily in many occupations and for one hour they receive instruction in the elements of education. This period of employment is certainly inconsiderable, if one compares it with the labour of adults, but even so it causes ill-effects among these children, from which they seldom completely recover. The power and ability of movement are completely lost and the height is obviously reduced. The knees, too, are often bent inwards and become weak. I have questioned some boys, who seemed to me to have scarcely reached the age of 6 , about their age, but I always found that they were much older than they looked. But after my investigation in the institution, I saw not a few who formerly lived there and I did not observe a single one among them who was tall. Accordingly it appears to me that there is nothing unsound in Cooper's opinion that deformity is caused by immoderate labour.

No less definite maladies occur in adult men although they are less frequent. Sometimes these illnesses occur in the conscientious heads of families and consist of indigestion, mental depression, and debility.

But the same amount of labour is not excessive for all men for men vary just as much in strength as they do in appearance. There is, however, a limit which most men observe and in factories in Great Britain men spend 12 hours daily on work. Dr. Bailey has in fact asserted that, in his opinion, 10 hours should be adequate. It is not unusual to observe that men enjoy the greatest health when they work to their fullest capacity, which seems to occur because at the same time they earn a bigger wage and accordingly their standard of life is more favourable.

\section{Muscular Effort}

Some diseases are caused by muscular effort. The most important of these are hernia and aneurysm. Not a few injuries also result from violent effort. Paviors,

\section{Labor Immodicus}

Mala, quae e labore immodico pendent, ut plurimum in liberis apparent. Hi ab inopia parentum, vel quod multo magis vituperandum est, ex avaritiâ magistrorum, longè juniores quam aequum est, ad laborem suscipiendum coguntur. Tres anni vix elapsi sunt, cùm Senatus Britanniae Magnae de hoc considerârunt, et regni medicos principes sententias rogaverunt. Ex his AsTLEY Cooper chirurgus, solus ab experientiâ doctus, testimonium dedit. Fama vero illius viri et scientia benè agnita, nihil de veritate opinionis nos sinunt dubitare. "Effectus," inquit ille illustris, " et ex multis exemplis cognovi, non tantum staturam diminuere est, sed pravitatem etiam membrorum producere."

Eodem tempore RoBERTUS OWEN a "New Lanark," interrogatus est, et testimonium ejus ad idem propositum fuit.

Experientia mea, si aliquid de illâ dicere liceat, sententiam COOPER illustris summoperè confirmat.

Birminghamiae asylum est, in quo liberi quadringenti habitant. Aetates horum a primo ad annum quartum decimum variant, nec ad laborandum ante septimam aetatem impelluntur. Eo tempore octo horas quotidie in multis operibus exercentur, unamque horam elementa doctrinae discunt. Paululum quidèm hoc, si cum labore hominum componas, attamen malum liberis infert, ex quo admodum raro, se recipiunt. Vigor et facilitas motuum prorsus amittuntur, et statura manifestè diminuitur. Genua etiam saepe intus inflexa et imbecillia fuerunt. Aliquos pueros scrutatus sum de aetate, qui mihi vix sextum annum attigisse videbantur, semper autem inveni multo annis, quam visu seniores. Post vero scrutationem in asylo, non paucos vidi, qui in illo olim habitaverunt, et ne unum quidem procerum inter omnes observavi. Mihi ergo nihil falsi in sententiâ COOPER apparet, deformitatem elabore immodico oriri.

In hominibus maturis mala non minus certa sunt, etiamsi rariora. Aliquando in diligentibus patribus familiarum occurrunt, atque in dyspepia, demissione animi et imbecillitate consistunt.

Labor tamen non omnibus idem est immodicus, viri enim robore aeque ac facie magnoperè differunt. Modus autem adest, quem plurimi sequuntur, atque in officinis Britanniae Magnae, homines quotidie labori duodecim horas impendunt. Doctor BAILEY quidem ait, decem horas satis esse debere, sed factum, se ipso judice, omnes theorias vincit. Non rarum est, homines optimâ valetudine frui, cum plurimum laborant, quod accidere videtur, quòd eodem tempore mercedem majorem obtinent, et dehinc ratio vivendi illis melior est.

\section{Conatus Muscularis}

Aliqui morbi e conatu musculari oriuntur. Horum hernia et aneurisma praecipui sunt. Vulnera quoque non pauca conatu vehementi producuntur. His morbis 
who lift particularly heavy loads, and all who are similarly employed, are exposed to these diseases. But sometimes hernia arises from less violent effort, if it is sustained for a long time. Thus I have known a boy to be affected by hernia. He was much engaged in turning a lathe and in the course of this work the femoral and abdominal muscles were simultaneously contracted. Glassblowers also occasionally suffer from this same condition. Again it is not uncommon for a hernia to appear between the fibres of the recti muscles of the abdomen when these are weak. Other accidents occur which bring no little harm to those who are injured. Such an instance is a tear of the muscle fibres, without evidence of external injury, as often occurs in the gastrocnemii. Healing is often slow and frequently the limb remains weak throughout life. Fractures, severe external wounds, etc., are less frequent and it is not necessary to discuss them.

\section{Posture}

Workmen are often exposed to many diseases due to the posture of the body. It is already well known that scholars are liable to unusual diseases, which cannot be attributed entirely or particularly to too long-continued occupation. Indeed there are many craftsmen, who work for equally long periods in these same positions, and who do not suffer ill-effects. Such persons are coppersmiths and iron-smiths, etc., but men who work in a similar posture to scholars suffer from similar diseases. Among these diseases indigestion is specially prominent. The signs of this condition are well-known and there is no need for many words. The disturbance of the state of the mind caused by this illness is often most troublesome and should be noted above all. This condition (indigestion) affects scholars and tradesmen alike. The illness has this symptom (pain in the stomach) less often in the case of scholars ; it is more common in tradesmen. The pain is severe and persistent, and it is never possible to cure it unless the patient has given up his occupation, which has caused the condition. Weavers, makers of brooches out of bone or pearl, polishers of metal brooches, etc., are liable to the illness with a variety of the symptoms described.

Pulmonary tuberculosis is produced by this cause (posture) and occurs in these same groups of workmen.

Deformity, particularly of the spine, is another condition due to posture. This not infrequently affects girls whose employment involves a good deal of writing. The condition does not necessarily follow this work, but it results from holding the left arm under the writing tablet while the right arm is applied to the top of it. In this way the rhomboid muscles are relaxed, the humerus of the same side is pushed upwards and the left scapula projects. On one occasion I saw a boy in whom, from this cause, five or six dorsal vertebrae were not a halfthumb's distance from the scapula. Treatmerit of this deformity consists in correcting the way of working, bending exercises, and resting ; and carrying weights on the head according to the circumstances. Dr. Macartney writing in the Philosophical Transactions of the Royal Society, London, has expounded learnedly on this deformity and its remedy. All should read this contri- pavimentorum structores, qui pondera praegravia evehunt, et omnes qui similia exercent, objiciuntur.

Sed e conatu minus vehementi, si diutius perduret interdum hernia provenit. Sic puerum novi, qui multum tornavit, in quo opere, saepissime musculi femorum abdominisque simul contrahuntur, herniâ affectum. Vitri conflatores etiam eodem morbo aliquando laborant ; et cum recti abdominis musculi, infirmi sunt, inter eorum fibras hernia non raro apparet. Alii quoque casus eveniunt non paululum incommodi laesis inferentes. Talis est musculorum fibrarum laceratio, sine vulnere externo, quae saepe gastrocnemiis accidit. Sanatio plerumque longa est, atque membrum saepe imbecillum usque ad mortem permanet. Infrequentiores sunt ossium fracturae, vulnera externa gravia etc. de quibus non necesse est, aliquid dicere.

\section{Positio Corporis}

E positione corporis, morbis multis et frequentibus homines patent. Jam dudum optimè notum est, literarum studiosos morbis peculiaribus objectos esse, qui neque omnino, neque praecipuè quidem $a b$ occupatione nimis continuâ originem ducunt. Artifices enim multi, quibus labores sunt aeque longi, iisdemque locis, simili valetudine adversâ non afficiuntur. Tales sunt aerarii ferrariique fabri etc. sed qui laborantes, eâdem positione corporis, quâ literarii, utuntur, similes morbi eos affligunt. Horum praecipuus dyspepsia videtur. Signa hujus morbi cognoscuntur, neque plurimis opus est. Illo affectorum animi infractio saepe maxime molesta, et prae aliis est notanda. Haec similiter literatos artificesque affligit ; haud raro autem dolor ventriculi ob pressuram isti organo factam, dyspepsiam comitatur. Minus saepe illis, frequentiùs his, ita morbus se habet. Dolor acutus est et praecipuè longus, nec unquam sanari potest, antequam occupationem aeger exercere cessaverit, unde exortus sit. Morbo sic variato textores, fibularum ex osse vel margaritis confectores, sutores, qui fibulas metallicas poliunt, etc. sunt obnoxii.

Ex eâdem causâ phthisis pulmonalis nascitur, et in iisdem fabris discernitur.

Alius effectus positionis corporis deformitas est, praesertim columnae vertebralis. Haec non infrequenter puellis accidit, quae multum in scribendo exercentur. Non necessariò hanc exercitationem sequitur, sed à sinistrum brachium subter tabulam tenendo oritur, dum illi dextrum imponitur. Hinc musculi rhomboidei relaxantur, humerus ejusdem lateris sursum fertur, et scapula sinistra prominet. Puerum quondam vidi, cujus quinque vel sex vertebrae dorsales non semipollicem a scapulâ sinistrâ ex hac causâ distabant. Sanatio hujus deformitatis est laborandi modum corrigere, inclinando, quiescere et pro re natâ capiti pondera sustinere. Doctor MACARTNEY hanc deformitatem et curationem in Act. Reg. Societat. Lond. scitissimè exponit, atque sermonem ejus de hâc re, omnes decet perlegere. 
bution on the subject. Some consider that haemorrhoids result from posture but this, however, is not established.

Ramazzini asserts, and the opinion is widely shared at present, that standing produces varicose veins. The particular evidence in support of this consists of observations on women who are engaged in washing clothes and it is a fact that women particularly are liable to varicose veins. However, it is not quite clear that the disease affects the women because of the position used in washing. For if standing produced varicose veins in one person, the same condition ought to affect others too who have to stand. Men, however, more rarely suffer from varicose veins than do women, yet more often daily they work standing. What then is the explanation why women more often suffer from varicose veins ? Pregnancy, it appears to me, is the reason as it is accompanied more or less generally by evidence of varicosity ; also the custom of constricting the popliteal veins at the knezs. These matters appear to have been overlooked by those who attribute the cause of varicose veins to posture. No one certainly can deny that these factors are most important. Accordingly I have not included varicose veins among the diseases of artisans.

\section{Light and Noise}

There is no need to discuss at length the subjects of light or excessive noise. Dimness of vision and hardness of hearing affect workmen whose jobs expose them unduly to bright light or great noise.

\section{Variations of Temperature}

Variations of temperature are a frequent cause of disease in artisans. In certain factories it is necessary to maintain the highest temperature. As a result the workmen sweat a great deal, and if they do not take precautions, which is very usual, a sudden congestion is caused by the cold on leaving the factory. The diseases from which these operatives are particularly liable to suffer are rheumatism, pneumonia or pleurisy, and catarrh. Pneumonia is uncommon and catarrh is less frequent in winter than in summer weather. The explanation of this appears to be that warmer clothing is worn in cold weather. Millers, glass-blowers, brewers, and similar workmen suffer in their health from this harmful influence of which I have just spoken.

But there is one disease, by far the most deadly, which is caused by changes of temperature. This is pulmonary phthisis and it seriously affects women employed in japanning.

\section{Mechanical Irritation}

Now I must deal with the most deadly cause of illnesses amongst tradesmen, namely mechanical irritation.

By mechanical irritation I mean that certain particles, which are not harmful in themselves, yet become harmful either by their quantity or because they attack the most sensitive part of the body. The habits of workmen exposed to this cause of suffering are very often intemperate. The nature of their work admittedly is an incitement to such habit, because it excites very great thirst and also they think that there are very few soft
Haemorrhoides aliqui aiunt, e positione corporis esse ; non tamen hoc certum est.

E pedibus insistendo, RAMAzzINI inquit, et sententia hodie communis est, varices provenire. Testimonium praecipuum, quo hoc sustentatur a mulieribus ducitur, quae vestimenta abluunt, et verum est, foeminas varicibus admodum obnoxias esse. Non tamen aeque manifestum est, morbum a positione quâ lavantes utuntur, illas premere. Si enim in pedibus sistere, huic varices producat, illum quoque similiter in pedibus sistentem eandem aegritudinem affligere oportet. Viri autem rarius quâm mulieres varices subeunt, tamen saepius atque diutius in pedibus sistentes laborant. Quae igitur ratio est, cur foeminae saepius varicibus afficiuntur? Graviditas mihi quidem videtur, quam varices plus minusve ferè comitantur ; et consuetudo poplites genualibus ligandi. Horum cogitationem illi omisisse apparent, qui causam varicum ad positionem referunt; nemo tamen negare potest, ea ad hanc rem plurimùm valere. Idcirco, varices inter morbos artificum non enumeravi.

\section{Lux et Sonitus}

De luce vel sonitu nimio, non necesse est, multum disserere. Oculorum caligo aut audiendi gravitas iis fabris contingunt, quorum opera, luce admodum fulgenti aut sonitu magno praesenti, conficiuntur.

\section{Temperiei Mutationes}

Temperiei mutationes morbos artificibus frequenter inferunt. In officinis quibusdam, necesse est, summum calorem conservare. Hinc fabris sudor magnus, et si prudentia absit, quae res saepissime occurrit, a frigore subita obstructio oritur, cúm officinas relinquunt. Morbi, quibus illi sic siti objiciuntur sunt prae omnibus rheumatismus, pneumonia vel pleuritis et catarrhus. Pneumonia infrequens est, et catarrhus hyeme quàm aestate infrequentior. Hoc accidere videtur, quia vestimenta hyeme calidiora sunt. Pistores, vitri conflatores, cerevisiae coctores et similes, valetudine ex adversâ causâ jam dictâ afficiuntur.

At morbus longe funestissimus e mutatione temperiei originem ducit. Hic phthisis pulmonalis est, et eas gravitèr affligit, quae modo Japonum aliqua ornant.

\section{Irritatio Mechanica}

Nunc de causâ artificum morborum, maximè dirâ tractandum est, nempe irritatione mechanicâ.

$\mathrm{Ab}$ irritatione mechanicâ, quasdam particulas per se innoxias intelligo, noxias tamen fieri, aut a quantitate earum aut quia parti praesertim excitabili corporis impinguntur. Fabrorum mores huic causae aegritudinis expositorum, sunt plerumque pravi. Opus vero ipsorum ad talem vitae rationem, incitamentum est. Sitim enim plurimum accendit, atque perpauci potus mites ad illam 
Needle grinding in Redditch a century ago.

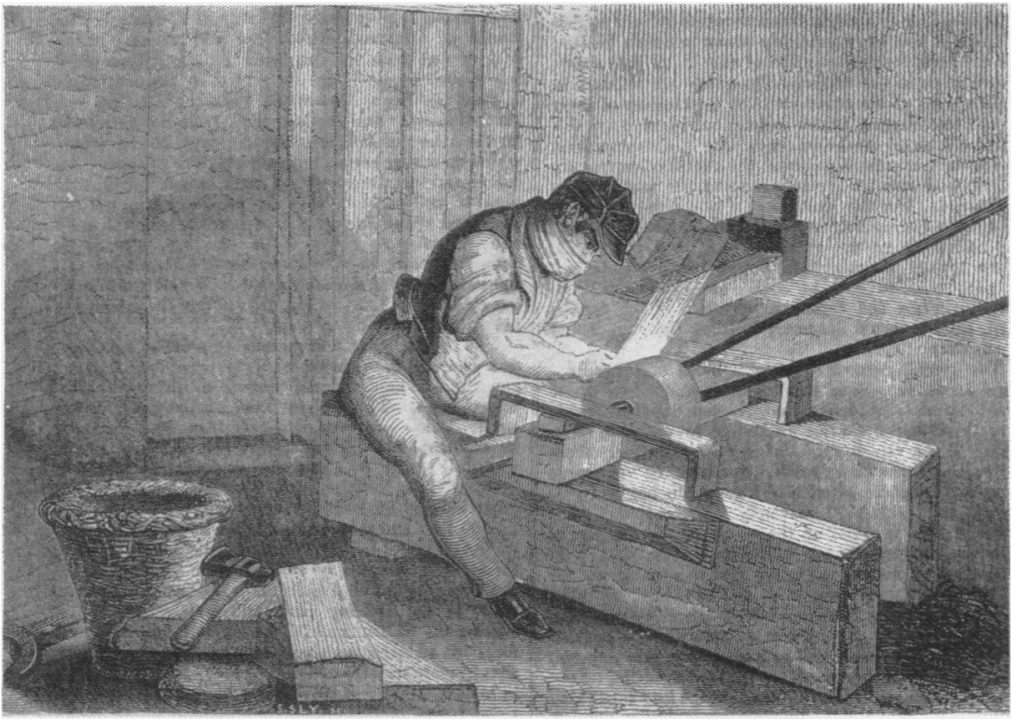

drinks which alleviate this so effectively as spirits and beer.

The air of the factories is completely loaded with dust, and the workmen cannot avoid inhaling it. This fact is best observed among factory operatives employed in pointing needles and swords. The artisans themselves have long been aware of the ill-effects arising from this work. The dust consists of stone and iron and the particles are extremely fine. If you inspect the workman's face, the particles which can scarcely be discerned, shine in it, and many collect inside the nares.

The disease to which such irritating air gives rise is pulmonary phthisis, and unless some other acute illness causes the earlier death of such workmen, all succumb to it. Men continue to work for 18 or 20 years without manifesting any sign of illness, although all the time they could not avoid the accumulation of dust within the lungs. About this period, beyond which few survive, coughing commences and the usual signs of phthisis immediately follow. That the disease does not arise earlier seems to me evidence that the lungs are not particularly susceptible to irritation, for if they were easily vulnerable to attack, the duration of the workman's life also should be shorter. The following groups of workmen are affected; needle-pointers and swordpointers ; gun-barrel grinders ; pearl and horn button makers ; grinders of iron or brass, and many other similar occupations. It is possible to entertain some doubt as to whether the dust really enters the lung; but although the dust is not found at post-mortem examination (which indeed ought not to be expected) many facts persuade me that this does occur. When I was investigating the facts relating to this subject, I entered, among others, a factory where gun-barrels are ground, and as I went near the grindstone I was covered with dust. Carelessly I inhaled, when suddenly I was seized with coughing which remained troublesome for 24 hours. Spasm of the glottis prevented the dust from entering compescendam tam idoneos, quam spiritus vini et cerevisiam existimant.

Aër officinarum pulvere quam maxime oneratur, et non potest esse, quin fabri illum inspirent. Hoc in illorum officinis, qui acus vel enses acuunt, optime notum est ; et mala ex eo orta, fabri ipsi jamdiu cognoverunt. Pulvis de lapide et ferro consistit et particulae minutissimae sunt. Si faciem scruteris, vix aspectabiles, in illam micant, et intra nares multae accumulantur.

Morbus cui aër sic exasperans originem praebet est phthisis pulmonalis; et nisi aliqua acuta aegritudo fabros tales antea perdiderit, $a b$ eâ omnes pereunt. Octodecim vel viginti annos, sine ullo valetudinis adversae signo, perstant laborare, quamvis pulverem in pulmonem necesse est continuò accumulari. Circa hoc tempus, cui pauci supervivunt, tussis incipit, et phthiseos indicia communia extemplò sequuntur. Morbum non citius oriri, mihi testimonium videtur, pulmones non valdè irritabiles esse, si enim facilè excitari possent, vita opificum etiam brevior esse deberet. Fabri sic affecti sunt, qui acus vel enses acuunt, qui tormentorum fistulas terunt, fibulas ex margaritis vel cornibus fabricant, ferrum vel aes abradunt. multique similes. Forsitan dubium videri possit, an pulvis re verâ pulmonem intret ; sed quamvis in sectione cadaverum non invenitur (quod non oportet quidem expectare) hoc accidere multa mihi persuadent. Cum res de hoc argumento scrutarer, inter alias officinas, eam visi, quâ tormentorum fistulae teruntur, et me lapidi appropinquantem pulvis circumdedit. Incautè inspiravi, cum statim mihi tussis erat, quae per quattuor et viginti horas molesta fuit. Meum ergo pulmonem glottidis contractio spasmodica, pulverem intrare prohibuit, non fabris vero haec occurrit. 
my lung, but this does not occur with workmen. Accordingly it is evident that the dust reaches the glottis, and unless the glottis is closed nothing prevents the dust from entering the bronchi, and if the bronchi, why not also the lungs? However, certain facts observed at post-mortem examination support this opinion. The lungs of workmen, who are employed in grinding iron or brass, present tuberculosis and the bronchi are similarly affected by the disease. The suffering also is such as we would expect from this cause. It is not the cough, nor the husky voice, nor even the breathlessness, which is always the first sign, but as I have found, unexpectedly, in persons who had died from other diseases, the lungs were damaged before any sign of the disease appeared. Probably asthma and throat ulceration arise from this same cause, mechanical irritation. In the greatest degree these diseases affect millers.

\section{Chemical Irritation}

The final theme of this discourse is chemical irritation, or an account of those diseases produced by harmful material handled by the workmen, or from the effluvia from the process or otherwise from emanations. This comprises those diseases which arise from the fumes of poisonous metals such as mercury, lead, etc., and those which alise from putrid effiuvia, as happens with butchers, chandlers (candlemakers), hide or skin dressers, and from bad air, called in English "fire-damp".

Of the diseases which are caused by poisonous metals, paralysis and shaking palsy caused by mercury are the most noteworthy. There are many who doubt if mercury is a harmful metal and certain individuals swallow great quantities without ill-effect. Orfila, the very distinguished French physician, who has written extensively on this subject, finally expresses this opinion : metallic mercury, it would appear, is most dangerous when in a state of extremely fine division.

Orfila writes as follows :

"Should metallic mercury be regarded as a poison? ... It appears to me that metallic mercury always acts as a poison if it lodges sufficiently long in the digestive tract to achieve a high degree of division and to be absorbed. We know that moisture and fat have a most remarkable power of breaking up the particles of this metal, indeed to the point that they become black. There is then no doubt whatsoever that in the first three instances recorded [in which metallic mercury caused the characteristic signs of the disease] the mercury retained in the body has been broken down by the stomach juices and by the fat with which it has been mixed in the area of the mercury. In this state of division it was absorbed and its harmful action proceeded with more or less force." (Orfila Toxocologie, Tom. 1, p. 120.)

The signs of shaking palsy are tremors of the head and limbs (usually affecting one side considerably more than the other), accompanied by abdominal pain, occasional purging, sleeplessness and also, after a time, mental derangement.

When the disease first attacks a person, the tremor is slight and occurs at longer or shorter intervals. At
Ad glottidem idcirco pulverem accidere manifestum est, et nisi rima glottidis claudatur, nihil impedit, quin bronchos ingrediatur, et si bronchos, cur non, etiam pulmones. E sectione cadaverum tamen, quaedam ad eandem sententiam adjiciuntur. Eorum pulmones, qui ferrum vel aes abradunt, tuberculas exhibent, et aeque ac bronchi morbo afficiuntur. Aegritudo etiam est, qualis ex causâ expectaremus. Non tussis, non vox rauca, non etiam dyspnoea semper primò est, sed ut inopinatè in interemptis ab aliis morbis inveni, pulmones ante noxam passi fuerunt, quam ullum signum morbi apparuisset. Ex eâdem causâ, videlicet, irritatione mechanicâ, asthma et excoriatio faucium interdum oriuntur. Hi morbi maximè apud illos qui molas curant, cernuntur.

\section{Irritatio Chemica}

Hujus sermonis, ultimum argumentum est irritatio chemica aut eorum morborum expositio, a materie noxiâ quâ fabri utuntur nascentium, aut effluviis ab opere vel aliter emissis. Haec eos comprehendit, qui a venenis metallicis, ceu hydrargyro, plumbo etc. qui ab effluviis putridis, ceu inter lanios, candelarum opifices, coriarios, atque ab aëre corrupto, Anglicè, " fire damp," proveniunt.

E morbis, qui a venenis metallicis nascuntur, paralysis tremens, ab hydrargyro, notatu est dignissima. An hydrargyrus metallicus noxius sit, multi dubitaverunt, et quidam pondera magna impunè devorarunt. ORfILA verùm Gallus celeberrimus multa de hac re disserens, tandem hanc statuit sententiam ; videlicet, hydrargyrum metallicum minutè divisum maxime nocere.

Haec sunt quae OrfiLA scripsit.

"Le mercure métallique doit-il être considéré comme un poison ?. . . Il me semble que le mercure métallique agit comme poison toutes les fois, qu'il séjourne assez de temps dans le canal digestif pour eprouver un grand degré de division et pour être absorbé. On sait que l'humidité et la graisse sont susceptibles d'atténuer prodigieusement les molécules de ce métal, an point qu'elles deviennent noires. Il n'est donc point douteux que dans les trois premiéres observations rapportées [in quibus hydrargyrus metallicus signa propria morbi induxisset] le mercure retenu dans le corps n'ait été divisé par les sucs de l'estomac et par la graisse avec laquelle il avait été mêlé dans la ceinture mercuriélle. Dans cet état de division il a été absorbé et son action vénéneuse s'est dévelopée avec plus ou moins d'énergie." OrfilA, Toxocologie, Tom. 1, p. 120.

Signa hujus paralyseos trementis, capitis et membrorum tremores sunt, fere unum vel alterum latus praecipuè occupans, cum dolore abdominis, dejectionibus paucis et insomniis et quodam post tempore imbecillitate animi.

Cum morbus aliquem capiat, tremor levis est et intervallis longis vel brevioribus occurrit. Primo manus 
first the hand or one arm shakes and the patient is unable to hold his tools. Thereafter the lower limb becomes weak and ultimately the disease spreads to all parts of the body. The bowels are usually confined, at some time there is diarrhoea and very frequently there is violent abdominal pain. By this time the workman is unable any longer to continue his job and is weak all the time. In many cases death soon results, but life, full of misery and distress, may continue for many years. Spirits or strong beer strengthen the limbs for a short time, but ultimately the disease, unhappy to relate, becomes worse.

No disease demonstrates more clearly the ineffectuality of medicine, for if drugs are not administered at the outset, the medical art can confer no beneficial effect on the patient, although neither the right moment to administer the medicines, nor the greatest mental acuteness are lacking in the physician.

I have observed the case of a man who suffered from this malady for 25 years and he had no power to hold anything. His head continually jerked from one side to the other ; his speech was interrupted by spasm of the vocal muscles, and his whole body shook without ceasing. He staggered a great deal in walking, and when he put his foot forward he shook it for a time in the air and then often drew it back again. This circumstance, happening suddenly, increased the convulsive movements, and whenever he became depressed in mind the disease got worse. His desire for food was the same as that of healthy people; his nights were peaceful and he slept very well. His evacuations were voluntary and natural. Although shaking palsy is the more common disease which is caused by mercury, it is not the more dangerous. Sometimes workmen exhibit all the signs of disease, which many previously considered to arise from syphilis. Ulceration of the mouth and throat, caries of the nasal bones associated with profuse salivation occasionally affect workmen handling mercury. Sound teeth also fall out due to ulceration of the gums and absorption of the alveolar sockets. By this time wasting not infrequently affects the patient, "and severe wasting takes place, and unless this is dealt with, it kills the patient". Drugs are certainly of no value in this disease, unless the patients have already given up attending at the factories.

Again among workmen engaged in processes in which white lead is used serious diseases likewise occur.

Not many years have passed since Sir George Baker published his discourse on painter's colic. As a cause of this disease he recognized the leaden vats, which are used to store apple juice. The malic acid dissolves the lead with the result that those who drink the liquid juice frequently suffer from severe pains in the bowels. However, although lead taken into the stomach causes disease it is not essential for the metal to make its way down into the bowel for the same effects to appear. Painters absorb fumes either through the skin or the lungs and they are liable to the same disease as those who drink cider. aut brachium unum solum tremit et aeger instrumenta non potest retinere. Dehinc membrum inferius infirmum fit et postea morbus ad omnes partes corporis extenditur. Alcus fere constringitur, aliquando diarrhoea adest, et dolor abdominis saepissimè est violentus. Jam opifex non amplius laborare potest atque omnino imbecillis est. Mors haud frequentèr sequitur, sed vita tristitiâ et miseriâ plena per multos annos permanet. Spiritus vini vel cerevisia fortis pro tempore brevi artus firmant, sed postea, miserabile dictu morbus gravior recurrit.

Morbus nullus medicinae impotentiam magis ostendit, si enim medicamenta in initio omittantur, ars nihil commodi potest aegro afferre, quamvis nec tempus administrandi nec acies summa mentis medico desint.

Hominem vidi qui hunc morbum per quinque et viginti annos laboraverat atque prehendendi aliquid nulla ei erat potestas. Caput nunc hinc nunc illinc perpetuo jactabat, loquela a musculorum vocis spasmo interrupta et totum corpus continuô agitatum fuit. Ambulando multum titubavit, et cum pedem promoveret, in aëre aliquantulum vibravit, et tunc non raro iterum retraxit. Huic eventus improvisò accidens convulsiones auxit, et quandocunque mens depressa fuit, morbus ingravescebat. Cupiditas cibi, ut sanis, noctes quietae erant, et optime dormivit. Evacuationes voluntariae fuerunt et naturales.

Quamvis paralysis tremens morbus frequentior, qui ex hydrargyro nascitur, non tamen periculosior est. Aliquando omnia morbi indicia opifices occupant, quae plurimi olim a syphilide oriri existimaverunt. Ulcera oris et faucium, caries ossium nasi cum salivae effusione copiosâ, fabros qui hydrargyro utuntur, interdum consumunt. Dentes etiamsi integri decidunt, propter gingivarum ulcera et processuum alveolorum absorptionem. Jam atrophia non raro aegrum invadit, "et summa macies oritur, et nisi occurritur, tollit." Huic morbo medicamenta haud prosunt, nisi aegri prius officinas cessârit frequentare.

In officinis atque operibus, ubi plumbum usurpatur, morbi admodum diri opificibus accedunt.

Non multi anni jam elapsi sunt, cum GeORGIUS BAKER, Baronettus, sermonem de colico pictonum edidit. Pro causâ hujus morbi, vasa plumbea, in quibus succus e pomis expressus servatur, cognovit. Acidum malicum plumbum dissolvit et dehinc quicunque succum sic imbutum bibunt, dolores colicos acutos frequentèr subeunt. Quamvis autem plumbum in ventriculum receptum morbos excitat, non necesse est, ut iidem effectus manifesti sint, metallum in alvum descendere.

Vapores per cutem aut pulmones pictores absorbent, atque eidem morbo cum illis qui succum pomorum bibunt, objiciuntur. 
The signs of painters' colic are most accurately described by Dr. Cullen as follows ;

" Painters' colic commences with a feeling of weight or discomfort in the abdomen, especially around the umbilicus ; followed by colicky pain, at first slight and intermittent, and increasing particularly after food ; then more severe and almost without remission, with pain in the arms and back, leading ultimately to paralysis."

In this description of the disease it is particularly worthy of note that Dr. Cullen embraced two diseases, most often occurring together, but also not infrequently occurring separately. Pain in the arms and back terminating in paralysis occurs frequently when the patient has never suffered from colic, and often colic, ending in death, tortures men whom paralysis has never affected. Orfila has extracted several such examples from the writings of Van Swieten.

The action of lead on the natural functions does not appear to be always the same. Often the patient, when the severe symptoms decrease, begins to waste away (or only the limb affected) and remains weak and free from convulsions. But Dr. Percival, writing in the Edinburgh Medical and Surgical Journal has recorded two instances in which the signs of the disease were similar to those caused by mercury. Orfila also described a case in which the arms were severely affected by tremors. Convulsions, however, seldom occur in this disease. Painters' colic occasionally persists for a long time and sometimes unless drugs are promptly administered, death follows after a short time.

Other metals, although harmful, do not often adversely affect workmen either because they are not extensively used, or are not easily absorbed or because they only very slightly give rise to fumes.

Now I come to the discussion of putrid animal effluvia. Ancient medical writers, and also several recently, have recognized putrid effluvia as a cause of typhoid fevers. Ramazzini, the most distinguished writer on this subject, and recently Dr. Gosse in the Quarterly Review of Foreign Medicine, support this opinion. However, while respecting the great name of Ramazzini, many facts convince me that the situation is otherwise ; and not only me but others whose reputation and authority among present-day day physicians are regarded in the highest degree. Of these, I may be permitted to mention Dr. Rush, formerly a physician in Philadelphia, Dr. Bancroft, writer on yellow fever, which attacks men in western India, and William Lawrence, one-time demonstrator in anatomy at St. Bartholomew's Hospital.

Dr. Bancroft has made extensive contributions to this subject and cited many examples in which there was considerable exposure to putrid effluvia, yet without causing fever or other illness.

This fact was particularly noted when decomposed corpses were removed from the cemetery of the Holy Innocents in Paris. The atmosphere was replete with putrid emanations and yet neither those living in the neighbourhood nor those engaged in the work suffered any illness. From this instance it is also possible to
Signa colicae pictonum accuratissime a Doctore Cullen describuntur.

"Colica pictonum, praeeunte ponderis vel molestiae in abdomine praecipue circa umbilicum, sensu; accedente dolore colico, primum levi, non continuo, et praecipue post pastum, aucto ; tandem graviore et fere perpetuo, cum dolore brachiorum et dorsi in paralysi demum abeunte."

In hâc descriptione verum notandum est, Doctorem Cullen duos morbos amplecti, saepissimè quidem conjunctos, non raro etiam separatim occurentes. Dolor brachiorum et dorsi in paralysi demum abiens frequenter accidit, cum aeger nunquam colicam perpessus est, et saepe colica homines torquet, in mortem desinens, quos paralysis, nunquam afflixit. Aliqua hujus rei exempla OrfiLA ab operibus Van SwIETEN extraxit.

Actio plumbi in functiones animalium non semper eadem videtur. Plerumque aeger, cum jam signa acuta desinunt, marcescit, (aut membrum affectum solummodo,) atque imbecillis et sine convulsione permanet, sed Dr. Percival in The Edinburgh Medical and Surgical Journal, duo exempla commemoravit, quibus signa morbi, iis quae ab hydrargyro oriuntur, similia fuerunt. OrfilA quoque unum exemplum dedit, in quo brachia maximè agitata sunt. Convulsiones tamen huic morbo raro accedunt. Colica pictonum aliquando longum tempus perduret, aliquando nisi medicamenta cito admoveantur, aegros brevi post tempore morti facit occumbere.

Allia metalla quamvis noxia, fabris morbos non saepe inferunt, aut quia non multum usurpantur, non facile absorberi possunt, aut vapores minimè emittuntur.

Nunc ad argumentum de effluviis putridis animalium venio. Auctores veteres medicinae, et plurimi etiam nuper effluvia putrida pro causa febrium typhoidearun agnoscunt. RAMAZZINI de hac re scriptor quidem celeberrimus, et recenter Dr. Gosse, in Quarterly Review of Foreign Medicine, hanc sententiam sustinent. Mihi tamen nomen magnum RAMAzZINI verenti, rem se aliter habere, multa persuadent, nec mihi solummodo, sed aliis viris, quorum fama et auctoritas inter medicos hodie est maximè clara. Inter hos Doctorem RusH, olim Philadelphiae medicinam exercentem, Doctorem BANCROFT de febre flavâ scriptorem, in India Occidentali homines occupanti, et GULIELMUM LAWRENCE quondam anatomiae demonstratorem in nosocomio Sancti Bartholomaei, enumerare licet.

Doctor BANCROFT de hac re copiosè disseruit, et plurima exempla dedit, ubi putredo maxima affuit, neque febris neque alius morbus consecutus est.

Praecipuè erat notabile cum cadavera putrida a sepulchreto Sant. Innocentium Parisiis removebantur. Aër putridis effluviis erat repletus, neque tamen illos qui circum habitabant neque eos qui in hoc opere versabantur, aliqua aegritudo afflixit. Ex hoc quoque 
adduce additional evidence on this subject. At that time the animal substance was discovered to which the French gave the name "adipocere", which so closely resembled spermaceti that the love of lucre induced some persons to manufacture that substance. These manufactures were located at Conham near Bristol, and the stench of the atmosphere was exceedingly vile, yet no ill-effect was observed among the workmen. Dr. Bancroft accompanied the military expedition to Egypt where each day he breathed putrid effluvia, yet neither he himself nor any of the soldiers, who transported the dead bodies, were upset in any way.

To this evidence may be added the opinion of William Lawrence, justly a highly celebrated man. Over a period of many years he dissected bodies, and demonstrated the parts of human bodies to students. But he himself never suffered any ill-effect nor did he ever observe that the students were affected by the putrid material. Even more worthy of remark is the instance of the family which lived for many years in the place where the bodies were dissected ; yet none of them ever enjoyed better or more lasting health.

Of this same fact chandlers (candlemakers) and skin or hide dressers provide proof. The stench in these workplaces is greater than in any others yet few persons enjoy better health. Butchers also, particularly those employed in slaughter-houses, never suffer any disease from this cause. Indeed in them appetite for food is increased and when they are attacked by any illness, it is accompanied by inflammation which clearly springs from excessive eating of flesh meat, in which they indulge.

From the gas, named by the English "fire-damp," asphyxia results. The condition is most frequently observed in miners but is less common, however, where the workmen use the lamps invented by Sir Humphry Davy.

Possibly there should be added cancer, which affects chimney sweepers, but the cause of this disease is still obscure.

These matters, which I have so briefly recorded, are the chief causes of the diseases which have been brought upon workmen by their occupations. But it is the greatest pity that these occupations, which are so essential, are harmful not so much in themselves as through excess and intemperance. This fact certainly is worthy of emphasis that the patients should remove these exciting causes, when they are known, for medicines can never be of real value, although generally beneficial, when these causes are continuously present. Although intemperance also frequently aggravates diseases and although the physician ought to prescribe a different way of life, the change must not be too sudden. The warning given by Celsus is very wise : "Whenever anyone wants something changed, he ought to accustom himself to it gradually."

And now I have completed this discourse. Many things, I am aware, have been omitted, and all imperfectly discussed. " But I hope I shall win forgiveness, particularly from brilliant professors, so long as it is clearly recognized that in a single city and district all occupations are not carried on," and I have not had the time to examine thoroughly all the matters which I have seen. aliud testimonium ad eandem rem adduci potest. Eo tempore substantia animalis inventa fuit, cui Galli nomen "adipocire" imposuerunt et quae spermaceti adeo simulabat, ut amor lucri quosdam ejus fabricationen efficere induxit. Haec ad CONHAM, juxta Bristolium situm habuit, ubi foetor aëris admodum graveolentus fuit, neque illis opificibus ullum malum unquam occurrerat. Expeditionem militarem Dr. BANCROFT in Aegyptum comitatus est, atque illic effluvia putrida quotidie respiravit, neque ipsi tamen, neque militibus, qui cadavera tulerunt, aliquid fuit incommodi.

His sententia Gulielmi LaWrence, viri multum et merito celebris accedit. Per multos annos cadavera incidit, atque partes corporis humani tyronibus demonstravit. Sed neque ipse unquam valetudinem adversam ex hoc expertus est, neque tyrones putredine affectos esse unquam percepit. Exemplum autem notatu longe dignius est, familiae, quae per multos annos loca habitabat, ubi corpora incisa fuerunt; nullis tamen erat melior salus aut magis diuturna.

Rei ejusdem candelarum opifices et coriarii testimonium praebent. Foetor nullis officinis quam illis major adest, pauci tamen valetudine meliore gaudent. Lanii quoque praesertim qui lanienas frequentant, nunquam morbis ex hoc subeunt. Quibusdam equidem cupiditas cibi augetur, et quando valetudo adversa eos occupat, cum inflammatione est, atque a victu nimio animali, cui indulgent, manifestè oritur.

E spiritu Anglice vocato "fire-damp" asphyxia provenit, et in quibusdam fodinis, olim saepissime accidit, rarior autem est, ubi lampas, quam HUMPHRY DAvY, Baronettus, finxit, usurpatur.

His fortasse accedit cancer, qui mundatores caminorum invadit, causa verum hujus morbi adhuc obscura est.

Haec quae tam breviter memoravi praecipuae morborum causae sunt, quos occupationes opificibus induxerunt. Sed maximè dolendum est, has occupationes, quae adeo sunt necessaria, non tantum per se, quantum per luxuriam et intemperantiam noxias esse.

Forsitan expectari possit, de curatione morborum quos artes inducunt, me disserere. Hoc verò ad consilium meum non pertinet, nec multum ratio sanandi differt quâcunque causâ hujusmodi morbus nascatur. Hoc quidem notandum, has causas excitantes, cum jam notae sunt, aegri removere debent, medicamenta enim nunquam possunt prodesse, utcunque fere utilia cùm illae continuo adsunt. Quamvis intemperantia quoque saepe morbos adauget, et rationem vivendi contrariam medicum decet praescribere, mutationem non subitam esse oportet. Optimè equidem Celsus admonet. " Cum quis mutari aliquid volet, paulatim debet assuescere."

Jam nunc hunc sermonem ad finem perduxi. Multa, bene scio, omitti, et omnia imperfectè tractari. "Veniam tamen, penes ingenuos professores praecipuè impetraturum me spero, dum satis perspectum est, non omnes artes in unâ civitate ac regione exercere" nec mihi tempus esse ut omnia illa quae vidi, perscrutarer.

FINIS 